\title{
Potato Seed Production Systems and Disease Prevalence in Major Potato Growing Regions in Kenya
}

\author{
L.M. Kamuyu ${ }^{1 *}$, W.M. Muiru ${ }^{1 *}$, J.W. Kimenju ${ }^{1}$ and M.W. Nyongesa ${ }^{2}$ \\ ${ }^{1}$ University of Nairobi, P.O. Box 30197-00200, Nairobi, Kenya \\ ${ }^{2}$ Kenya Agricultural Livestock Research Organization, P. O. Box 14733-00100, Nairobi, Kenya \\ *Corresponding author
}

\section{A B S T R A C T}

\begin{tabular}{|l|}
\hline Ke y w o r d s \\
Bacterial wilt, \\
Farming practices, \\
Potato leaf roll \\
virus, Prevalence, \\
survey.
\end{tabular}

Seed-borne diseases are a major problem in Kenya since many farmers have no access to certified seeds. The objective of the study was to study the influence of potato seed production systems on potato seed borne diseases. A survey was carried out in five major potato growing counties in various agro-ecological zones (AEZs). An open ended questionnaire was administered to 59 farmers to collect information on farming practices and disease parameters. Most of the farmers apart from Kiambu County use their own farm saved seeds, buy from the local market and from their neighbors. Some farmers renew seeds from reliable sources with Kiambu leading with about $80 \%$ followed by Nakuru (27.3\%), Nyandarua (18.2\%) and Meru (13.6\%) respectively. Bacterial wilt disease and potato leaf roll were detected in all the counties. In case of bacterial wilt, the highest prevalence was in Nyeri County with a prevalence of $90.0 \%$, followed by Meru and Nyandarua each with $81.8 \%$. Most farmers' use poor quality seeds and due to small farm sizes they are unable to practice crop rotation leading to high prevalence's of bacterial wilt and potato leaf roll virus.

\section{Introduction}

Potato is an important crop in Kenya and it ranks fourth among the four major crops grown that include rice, wheat and maize (Hoffler, 2008; FAO, 2008). It provides high incomes for small scale farmers and it is a potential source of employment to many people both directly and indirectly (Mbaka et al., 2013). Seed quality is affected by biological aspects such as the level of disease infection and physiological age of seed tuber. Tuber seeds planted continuously for several years show degeneration which is a result of viruses and virus-like organisms which accumulate in tubers. The major viruses infecting potato and lowering potato seed quality are mainly potato leaf roll virus, potato virus $\mathrm{Y}$, potato virus $\mathrm{X}$, potato virus $\mathrm{A}$ and potato virus $\mathrm{M}$ (FAO, 2008). Bacterial wilt is a serious threat to tomato production due to limited strategies to control the disease effectively and farmers are abandoning cultivation of the crop due to the disease (Mbaka et al., 2013).

To guarantee quality, seed should be free from bacteria, viruses and fungi which may lead to seed degeneration (FAO, 2010). Production of certified seed potato starts with 
in-vitro plantlets from meristematic tissue in tissue culture laboratory. Plantlets are multiplied and after hardening, they are planted in sand media in greenhouses to produce mini-tuber seeds which are multiplied in the field for three generations to produce basic seed (Mbiyu et al., 2012; Muthoni et al., 2013). There has been lack of enough certified seeds to be supplied to farmers and this has forced farmers to plant seeds from their own farms and other sources. These poor quality seeds increase the rate of spread of seed-borne diseases such as bacteria wilt leading to high incidence and prevalence. Previous research indicates that bacterial wilt is found in all the potato growing areas of Kenya affecting $77 \%$ of potato farms followed by late blight (69\%) (Peeters et al., 2013; Kaguongo et al., 2010).

Although crop rotation can reduce disease incidences, many farmers were not able to practice it due to the small farm sizes (Muthoni et al., 2013). Cropping cycle using seeds from the same farms without renewing from reliable sources also contributes to the accumulation of seed-borne diseases namely bacterial wilt caused by $R$. solanacearum (Tahat et al., 2010) and viral diseases such as PVY and PLRV which are the major potato diseases. Poor quality seeds reduce potato quality and yields (Gidemacher et al., 2009).

\section{Materials and Methods}

The survey was conducted in the major potato growing counties in Kenya namely Nyeri, Nyandarua, Meru, Nakuru and Kiambu (Figure 1). The farms surveyed ranged in altitude from 2079 to 2617 meters above sea level (masl). The agro-ecological zones surveyed for the various counties were MeruUH3 (wheat and barley zone), Nyandarua UH3 (wheat-barley zone), Molo Elburgon UH2 (pyrethrum - wheat zone), Nyeri-LH4 \& LH3 (cattle-sheep zone) and Kiambu-LH3 (cattle-sheep zone) (Jaetzold et al., 2007). In these counties, potato crop is grown for food consumption and commercial purposes.

In each surveyed county, farms were selected at random in the counties about $2-4 \mathrm{~km}$ from each other. During the survey, bacterial wilt and potato leaf roll virus disease incidences were recorded per sampled farm. During the survey, a total of 59 farmers were interviewed and these included Nakuru (11), Nyandarwa (11), Meru (22), Nyeri (10) and Kiambu (5). Information was collected using an open ended questionnaire to allow individual farmer to express themselves and to be able to gather much responses on the potato seed production systems. The information covered included farmers' practices such as source of seeds, seed renewal, cropping cycle, area under potato production and disease prevalence. The collected data was recorded and analyzed using Statistical Package for Social Sciences (SPSS Inc. (2009). Visual assessment of the farms showing symptoms of bacterial wilt and potato leaf roll virus was done and disease severity and prevalence per sampled farm recorded.

Information on geographical positioning system (GPS) was collected namely elevation, longitude and latitude for mapping the position of the sites of survey using geographical information system (GIS). Samples were collected from farmers, certified seed and registered seed merchant systems, and taken to KEPHIS Laboratories at Muguga and analyzed for latent infection of bacterial wilt caused by Ralstonia solanacearum and viruses. Presence of bacterial wilt and viral diseases on the collected samples was achieved using both serology and conventional methods. Nitrocellulose membrane-ELISA (NCMELISA) was used for bacterial wilt screening while Double Antibody Sandwich-Enzyme Linked Immuno-Sorbent Assay (DAS- 
ELISA) kit by Centre for International Potato (CIP) was used in the detection of viruses. Results were confirmed using FORSITE quick diagnostic kits from Central Laboratory U.K. for detection of bacterial wilt and viruses.

\section{Results and Discussion}

A total of fifty nine (59) farmers were interviewed and these comprised of $37.3 \%$ from Meru, Nakuru 18.6\%, Nyandarua $18.6 \%$, Nyeri $16.9 \%$ and Kiambu $8.5 \%$ The land allocated to potato production varied from 0.3 ha to 0.7 ha, with Nakuru having the highest acreage under potato production of 0.7 ha followed by Kiambu with 0.5 ha, Meru 0.4 ha, Nyandarua 0.3 ha and Nyeri-Kieni East with the lowest acreage of 0.3 ha.

Eighty percent $(80 \%)$ of farmers in Kiambu County obtain clean potato seeds from KALRO Tigoni, (10.3\%) farmers from Meru obtain potato seeds from Kisima Farm. Farmers from Nakuru, 20\% source seed from Turi Farm and for Nyandrua 15\% of the farmers' source seed from KALRO Njabi-ini. Farmers from the five counties also obtains high percentage of seeds from their own farms with Nyandarua leading with $69.2 \%$, followed by Meru $65.5 \%$, Nyeri $60 \%$, Nakuru $46.7 \%$ and Kiambu 20\%. Farmers also buy seeds from neighbours and market with Nyeri having $40 \%$, Nakuru $33.3 \%$, Meru $24.1 \%$ and Nyandarua $15.4 \%$. There was a positive correlation between seed source and disease incidence with Kiambu and Nakuru having low bacterial wilt and potato leaf roll virus compared to the other counties. Seed source and incidence of BW and PLRV were either positively or negatively correlated. Where farmers were using certified seeds, there were fewer incidences of BW and PLRV. Where farmers were obtaining seeds from their own farms and neighbours there were high levels of BW and PLRV (Figures 2 and 3).
Some of the farmers interviewed renewed potato seed from reliable sources with Kiambu leading with $80 \%$ followed by Nakuru $27.3 \%$, Nyandarua $18.2 \%$ and Meru 13.6\%. In Nyeri Kieni -East $1.0 \%$ of farmers renew seeds from reliable sources (Table 1). The study showed that $60 \%$ of the farmers interviewed did not renew the potato seed from reliable sources but used seeds from their own farms or purchased them from their neighbours. Use of uncertified planting seed increases seed borne diseases like BW and PLRV.

There was a negative correlation between seed renewal and disease incidence and this can be clearly seen in Nyeri county where most of the respondents did not renew seed. Regression analysis showed a negative correlation between increase in seed renewal with decrease in disease prevalence (Figures 4 and 5). Nyeri had bacterial wilt incidence of $90 \%$ and PLRV of $80 \%$ which is relatively high compared to other counties like Kiambu and Nakuru with PLRV of between 36.4\% and $40 \%$. Bacterial wilt disease incidence was relatively low between $60 \%$ and $64 \%$ in comparison with Nyeri.

Bacterial wilt disease was detected in all counties and the prevalence was highest at $90 \%$ in Nyeri followed by Meru with $82 \%$, Nyandarua $82 \%$, Nakuru $64 \%$ and Kiambu $60.0 \%$. There was no significant difference in prevalence of bacterial wilt in the five counties. The study also showed that most of the farmers in Nyeri do not source seeds from reliable sources and therefore bacterial wilt prevalence was highest in the area. Bacterial wilt prevalence was lower in Kiambu County at $60 \%$ where $80 \%$ of farmers obtain seeds from reliable sources than in Nyeri $90 \%$, Meru $82 \%$, Nyandarua $82 \%$ and Nakuru 64\% (Table 2). There was a significant correlation between clean seeds use and disease prevalence where bacterial wilt disease 
decreased with increase in clean seed with correlation of $\mathrm{R}^{2}=0.6529$ for $\mathrm{BW}$ and PLR value as $R^{2}=0.4251$.

Potato leaf roll virus was also observed in all the five counties and Nyandarua was leading with $90.9 \%$, followed by Meru with $86.4 \%$, Nyeri $80 \%$, Kiambu $40 \%$ and Nakuru $36.4 \%$ but it was low in Nakuru and Kiambu compared to all the other counties. Farmers in Kiambu and Nakuru obtain $80 \%$ and $20 \%$ of potato seeds for planting from reliable sources, respectively and this may have contributed to low potato leaf roll incidence.

Potato is grown in all the counties that were surveyed and Meru was leading with $56 \%$ of respondents growing the crop, followed by Kiambu with 55\%, Nakuru 50\%, Nyeri $48 \%$ and Nyandarua 40\%. Other crops widely grown are cabbages and maize, with Kiambu having $28 \%$ of respondents growing cabbages and $15 \%$ growing maize and beans. In Meru $12 \%$ respondents were growing cabbage and carrot and $27 \%$ maize and beans while in Nakuru county, the crops grown were Maize + beans by $19 \%$ of respondents and rhodes grass grown by $14 \%$ of the respondents. Respondents in Nyandarua County also grew other crops besides potato and these are cabbages, oat and carrot while $38 \%$ of farmers in Nyeri grew maize and bean and $12 \%$ of the respondents were growing cabbages and carrot respectively (Table 3 ).

The most frequent crops sequences in the five counties surveyed in Kenya are two years' rotation. In Meru county, the rotation is for two years involving potato, maize + beans or cabbage and potato. In Nyandarua, farmers also practiced two years' rotation of potato, cabbage or carrot or pea and those surveyed in Nyeri did the same with potato, beans or maize, cabbage, potato. Farmers in Kiambu mainly planted potato, followed by cabbage, maize + beans and potato while at Nakuru they plant potato, maize + beans, rhodes grass and potato.

Table.1 Proportion of farmers who renew seed in the five counties

\begin{tabular}{lccccc}
\hline \% Respondents & \multicolumn{5}{c}{ Counties } \\
& Kiambu & Meru & Nakuru & Nyandarua & Nyeri \\
Do not renew & 20.0 & 86.4 & 72.7 & 81.8 & 99.0 \\
Renew seed & 80.0 & 13.6 & 27.3 & 18.2 & 1.0 \\
\hline
\end{tabular}

Table.2 Percent disease prevalence for the counties

\begin{tabular}{lcc}
\hline County & Bacterial wilt prevalence & PLRV prevalence \\
\hline Kiambu & 60.0 & 40.0 \\
Nakuru & 63.6 & 36.4 \\
Meru & 81.8 & 86.4 \\
Nyandarua & 81.8 & 90.9 \\
Nyeri & 90.0 & 80.0 \\
\hline
\end{tabular}


Table.3 Crops grown in each of the five counties and the \% age of respondents Growing each crop

\begin{tabular}{lrrrrc}
\hline & Kiambu & Meru & Nakuru & Nyandarua & Nyeri \\
\hline Cabbage/carrot/pea & 28.0 & 12.0 & 5.0 & 36.0 & 12 \\
Maize+Beans/pea & 5.0 & 10.0 & 19.0 & 10.0 & 28.0 \\
Banana & 10.0 & 17.0 & 0.0 & 0.0 & 10.0 \\
Napier grass & 1.5 & 3.0 & 5.0 & 0.0 & 2.0 \\
Oat & 0.0 & 0.0 & 0.0 & 14.0 & 0.0 \\
Potato & 55.0 & 56.0 & 50.0 & 40.0 & 47.0 \\
Rhode grass & 0.5 & 0.0 & 14.0 & 0.0 & 1.0 \\
Wheat & 0.0 & 2.0 & 7.0 & 0.0 & 0.0 \\
\hline
\end{tabular}

Fig.1 Map showing areas where the study was carried out

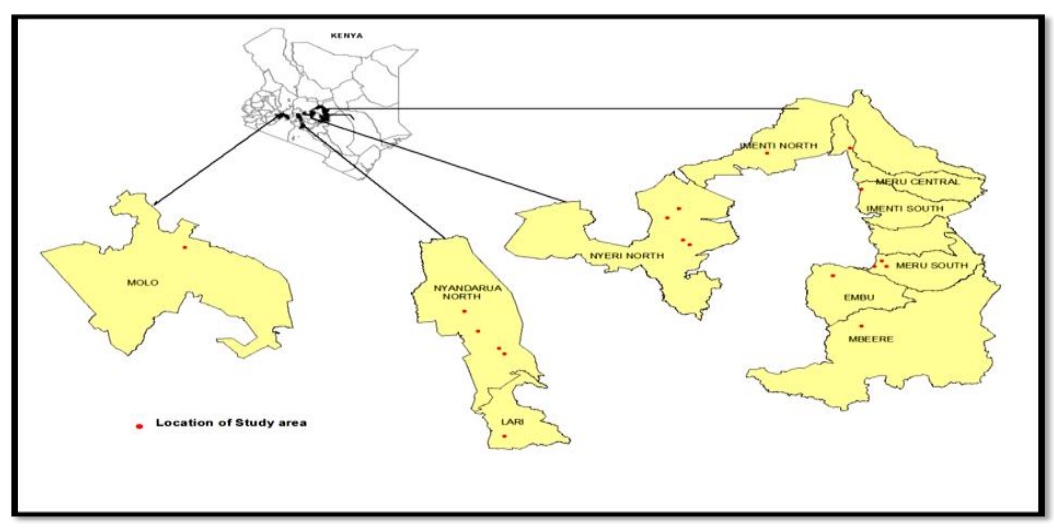

Fig.2 Correlation between bacterial wilt prevalence and farmers obtaining potato seeds from different sources

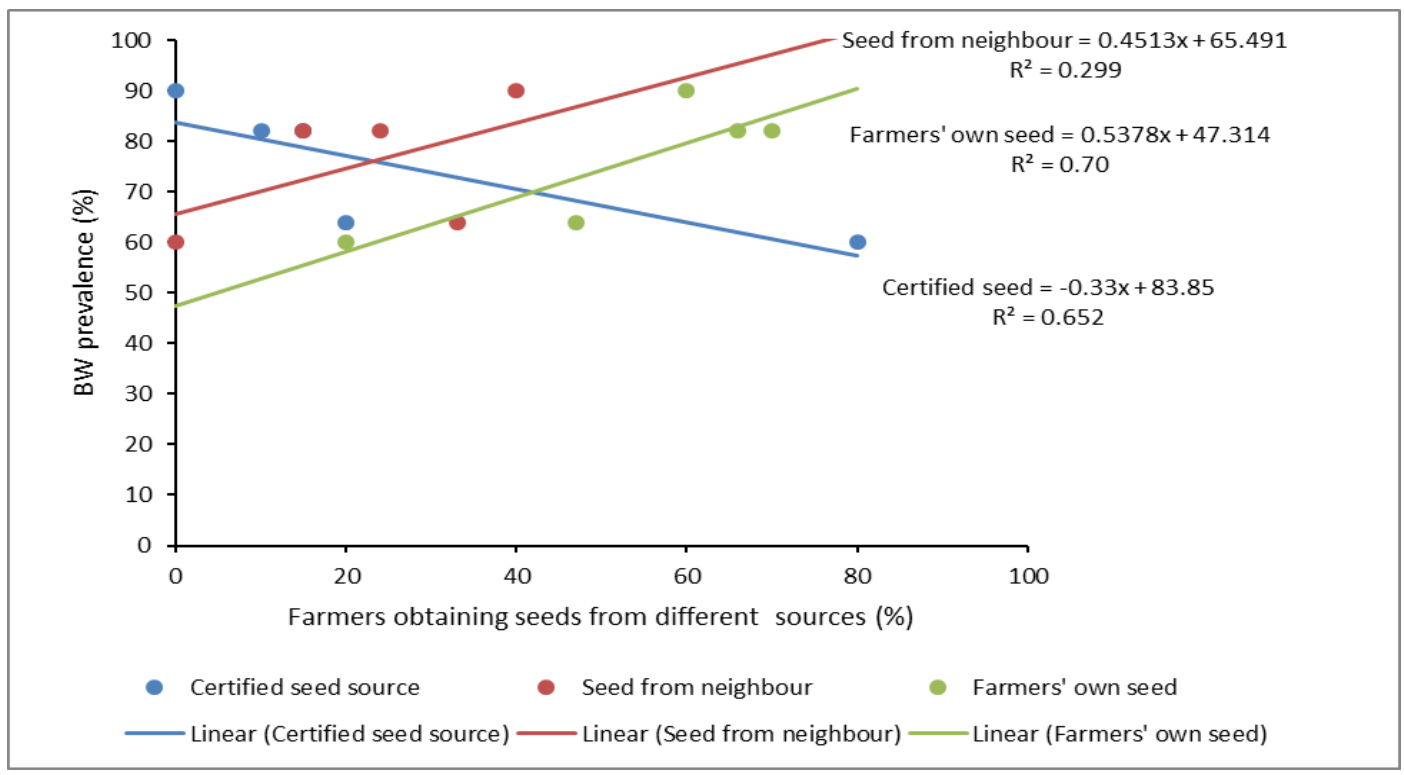

Key: BW Bacterial wilt 
Fig.3 Correlation between potato leaf roll virus prevalence and farmers obtaining potato seeds from different sources

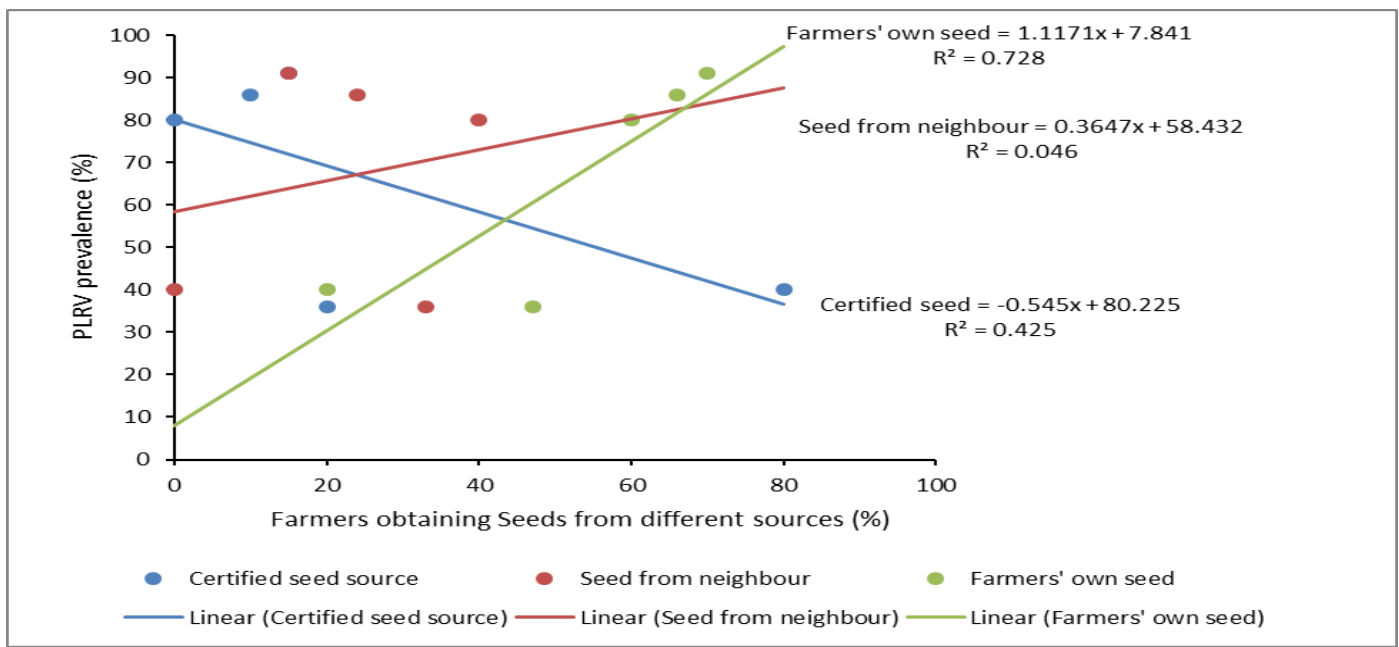

Key: PLRV Potato leaf roll virus

Fig.4 Correlation between bacterial wilt prevalence and number of farmers renewing seeds

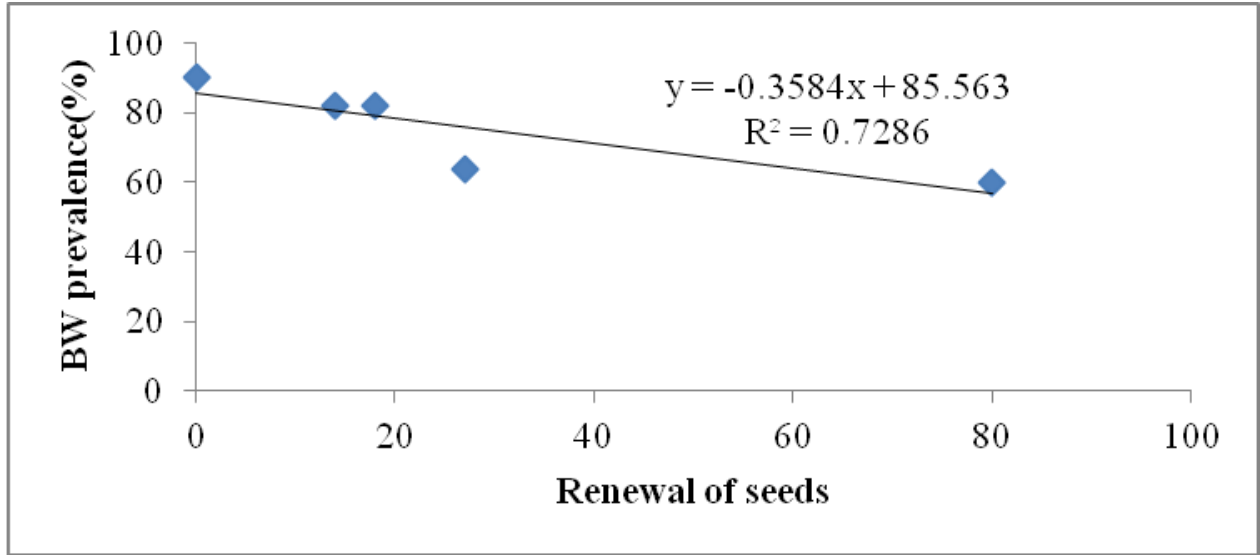

Fig.5 Correlation between potato leaf roll virus prevalence and number of farmers who renew seeds

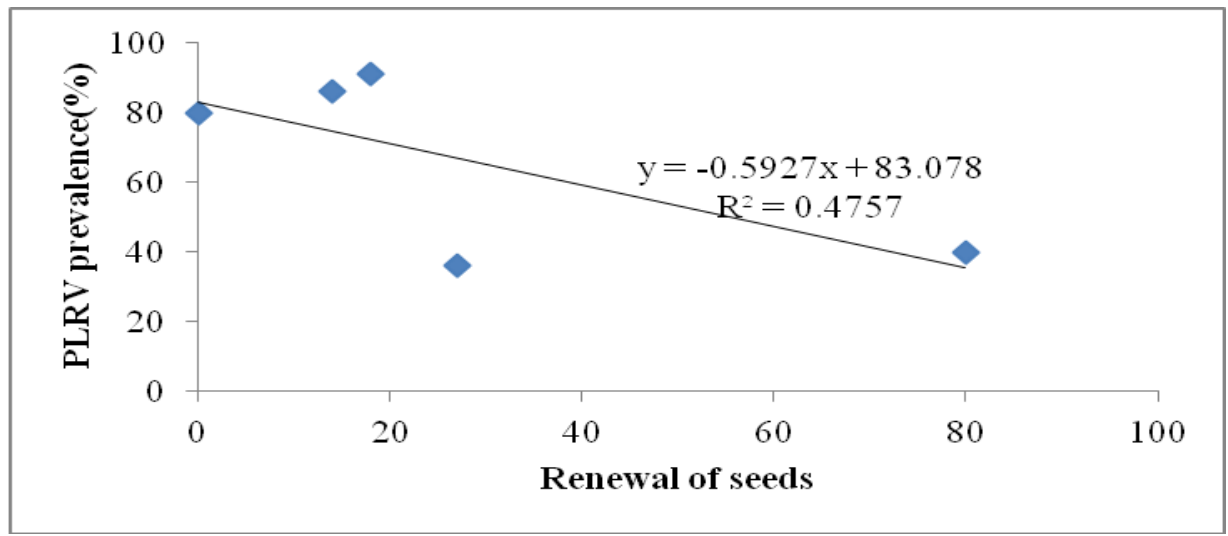


In Meru county where cropping cycle involves potato rotated with maize or cabbage, BW prevalence was $81.8 \%$ and PLRV was $86.4 \%$. In Nyandarua BW was high up to $90.0 \%$ and PLRV was $90.9 \%$. In Nyeri where crop rotation is between potato and maize or beans, BW incidence was $90.0 \%$ and PLRV incidence was $80.0 \%$.

The study revealed that bacterial wilt was distributed in all the five counties surveyed with a higher prevalence being reported in the high altitude areas. The prevalence of bacterial wilt was lower in Kimbu and Nakuru compared to Nyandarua and Meru which have higher altitude than other counties. This was not expected because these counties lie within high altitude areas (Jaetzold Schmidt, 2007). Strains of $R$. solanacearum have been reported in many parts of the world and it affects over 200 plant species in over 50 families (Champoiseau and Momol, 2009).

The findings showed that farmers obtain seed which are of poor quality from their own farms and neighbours and continue planting them year after year without renewing them from reliable sources and this contributes highly to the problem of bacterial wilt and viruses. In the past, research reported incidence of bacterial wilt at altitudes of 2942 masl which was contributed by factors like source of seeds (Ateka, et al., 2001). Comparatively, Meru County produced more potatoes than the other four counties surveyed with 56\% respondents growing the crop. The average farm size under potato production ranged from 0.3 to 0.7 ha for the counties surveyed with Nakuru leading followed by Meru and Kiambu. It is clear that the sizes of the farms in the areas surveyed are relatively small (less than a hectare) and farmers were not able to practice long period of crop. The problem of small farm sizes has been limiting long crop rotation (Lutaladio et al., 1995). Farmers were also replanting poor quality potato seeds in the same farm and this increased disease incidence and prevalence. This agrees with report by FAO (2008) which indicates that use of low quality seeds in SubSaharan Africa contributes to the low average yields.

Most respondents (69\%) obtained seeds from their own farms and Nyandarua led with 69\% while others obtained seeds from neighbours. Nyeri county had the highest percentage of farmers who obtained seed potato from neighbours. Renewal of seeds was done by a few farmers except Kiambu farmers who obtained clean seed potato from KARLO. Own farm seed potatoes are usually of poor quality and planted continuously for several years, they show degeneration of tubers which is a result of viruses and virus-like organisms that accumulate in them (FAO, 2010).

Farmers who used seeds from their own farms had very high prevalence of bacterial wilt and viruses. Farmers in Nyandarua county used their own seed (69.3\%). These results show that most farmers in the surveyed region do not renew seed and this explains the high incidence and prevalence of bacterial wilt and viral diseases. Due to lack of certified seed potatoes for planting farmers plant poor quality seeds from their own farms and this increases seed-borne diseases leading to high incidences and prevalence of BW and PLRV. Previous research indicates that Ralstonia solanacearum is a wide spread pathogen and $77 \%$ of potato farms in Kenya are affected by the disease (Muthoni et al., 2013; Peeters et al., 2013).

Rotation sequences also play a role in disease prevalence and it can be seen that in Nakuru where potato is rotated with rhodes grass, maize, and other none related crops, PLRV was low. Previous research shows that planting potato crop from the same farm without rotation with none host crop leads to 
poor quality seed potato due to degeneration of tubers caused by viral diseases (FAO, 2010). It was noted that even where rotation was done with non- host crop, the incidence and prevalence of bacterial wilt and potato leaf roll was high and this was due to replanting diseased potato seeds from the same farms. Most farmers could not meet the rotation sequence recommended because the farm sizes are small.

\section{Acknowledgement}

Kenya Plant Health Inspectorate Service (KEPHIS) is acknowledged for the financial support to undertake this study and the University of Nairobi for supporting the research work in providing the facilities to conduct the research.

\section{References}

Ateka, E. M., Mwang'ombe, A. W., Kimenju, J. W., 2001. Reaction of potato cultivars to Ralstonia solanacearum in Kenya. African Crop Science Journal 2001, Vol.9 No. 1: 251-256.

Champoiseau, P. G., and Momol, T. M. 2009. Training modules on Bacterial wilt of tomato. University of Florida IFAS extension.

http://plantpath.ifas.ufl.edu/rsol/Trainin gmodules/BWTomato_Module.html

FAO,

http://faostat.fao.org/site/567/default.as px, June 2008.Rome: FAO.

FAO, 2010. W.w.w.fao.org/docrep/010/io200 E08.htm. Potato priority in Asia and Pacific Region.

Gildemacher, P. R., Barker, I., Kaguongo, W., Woldegiorgis, D., Wakahiu, M., Leeuwis, C., Struik, P. C., 2009. A description of Seed Potato Systems in Kenya, Uganda and Ethiopia. American Journal of potato research, Oct. 2009 Vol. 86, Issue 5, pp 373-382.
Hoffler, H., Ochieng B.O., 2008. High Commodity Prices - Who gets the Money? Preliminary findings for World Food Day 2008. Heirich Boll Foundation. Food and Agriculture Organization of the United Nations. International Year of the Potato, 2008. www.potato2008.org.

Jaetzold R., Schmidt H., 2007. Natural condition and Farm management information handbook of Kenya, $2^{\text {nd }}$ Edition. Ministry of Agriculture, Kenya in Cooperation with German Agricultural Team (GAT) of the German Agency Technical Cooperation (GTZ). Vo II: Composition by Erhart Gmbh, printed by typo-druck, Rossdorf, W-German 1983.

Kaguongo, W., Ng'ang'a, N., Muthoka, N., Muthami, F., Maingi, G., 2010. Seed potato sector master plan for Kenya (2009-2014). Seed potato study sponsored by GTZ-PSDA., USAID, CIP and Government of Kenya, Ministry of Agriculture, Kenya.

Lutaladio, 1995. International potato center: World potato Atlas.

Mbaka, J. N., Gitonga, J. K., Gathambari, C. W., Mwangi, B. G., Githuka, P. and Mwangi, M. 2013. Identification of knowledge and technology gaps in high tunnels tomato production in Kirinyaga and Embu counties. https://www.google.com/\#q=bacterial+ wilt+tomato+kirinyaga

Mbiyu, M. W., Muthoni, J., Kabira, J. N., 2012. Use of aeroponocs techniques for production of potato mini tubers, Journal of Horticulture and forestry Vol. 4(11), pp172-177, Nov 2012 ISSN 2069782- review @ 2012 academic journals, Tigoni, Kiambu, Kenya.

Muthoni, J., Shimelis, H. D., Melis, R., 2013. Potato production in Kenya: Farming System and Production Constraints. Journal of Agricultural Science; Vol.5, 
No.5; 2013. Published by Canadian Centre of Science and Education April 15, 2013.

Peeters, N., Guidot, A., Vailleau, F. and Valls, M. 2013. Rastonia solanacearum, a widespread bacterial plant pathogen in the post-genomic era. Molecular Plant Pathology 14(7): 651-662.
SPSS Inc. 2009. Statistical Package for Social Science SPSS for Windows Release 18.0.2009. SPSS Inc. 2009. Chicago IL. Retrieved from www.spss.com.

Tahat, M. M., and Kamaruzaman S., 2010. Ralstonia solanacearum: The Bacterial Wilt Causal Agent. Asian Plant Sciences 9: 385-393

\section{How to cite this article:}

Kamuyu, L.M., W.M. Muiru, J.W. Kimenju and Nyongesa, M.W. 2017. Potato Seed Production Systems and Disease Prevalence in Major Potato Growing Regions in Kenya. Int.J.Curr.Microbiol.App.Sci. 6(10): 1012-1020. doi: https://doi.org/10.20546/ijcmas.2017.610.122 